\title{
Effect of Rooting Promoters on the Rooting and Growth of Cuttings in Several Flowering Shrubs
}

\author{
Hyun Hwan Jung, Ki Young Park, O Hyeon Kwon, and Bong Sik Yoo* \\ National Institute of Horticultural \& Herbal Science, RDA, Wanju-gun 55365, South Korea
}

\begin{abstract}
This study was conducted to investigate the effects of rooting promoters on rooting and seedling quality in Buddleja davidii 'Empire Blue', Hydrangea paniculata 'Magical Candle', Hydrangea arborescence 'Annabelle', Stephanandra incisa semi-hardwood cuttings. IAA and IBA $\left(500,1000\right.$, or $1500 \mathrm{mg} \cdot \mathrm{L}^{-1}$ soaking for 30 minutes and $3,000 \mathrm{mg} \cdot \mathrm{L}^{-1}$ dipping for 10 seconds) or Rootone ${ }^{\mathrm{TM}}$ were used as rooting promoter. In $B$. davidii 'Empire Blue', IBA $1,500 \mathrm{mg} \cdot \mathrm{L}^{-1}$ soaking reduced rooting percentage than control, but the effect of rooting promoters was generally insignificant. Number of leaves and shoot length were reduced in Rootone ${ }^{\mathrm{TM}}$ and IBA $1,500,3,000 \mathrm{mg} \cdot \mathrm{L}^{-1}$ treatments. IAA $1,000 \sim 3,000 \mathrm{mg} \cdot \mathrm{L}^{-1}$ and IBA $500 \mathrm{mg} \cdot \mathrm{L}^{-1}$ treatments showed better mat formation than control. The rooting ratio of $H$. paniculata 'Magical Candle' increased to $66.7 \%$ in IBA $1,500 \mathrm{mg} \cdot \mathrm{L}^{-1}$ soaking treatment compared with $26.4 \%$ in the control. The mat formation was higher in Rootone ${ }^{\mathrm{TM}}$, IAA and IBA treatments compared to control, and root length showed longer tendency in IAA and IBA except Rootone ${ }^{\mathrm{TM}}$. The rooting ratio of $H$. arborescence 'Annabelle' was highest at $70.8 \%$ in the control and auxin treatments showed negative effect on the rooting percentage except IAA $1,000 \mathrm{mg} \cdot \mathrm{L}^{-1}$ soaking treatment. The mat formation was very poor in IBA 1,000 and $1,500 \mathrm{mg} \cdot \mathrm{L}^{-1}$ soaking at 1.1 and 1.3 , respectively. S. incisa showed high rooting percentage at RootoneTM $(80 \%)$ and IAA $1,500 \mathrm{mg} \cdot \mathrm{L}^{-1}$ $(80 \%)$ treatments compared to control (51.7\%). Root length and dry weight were high in IAA $1,500 \mathrm{mg} \cdot \mathrm{L}^{-1}$ soaking treatment. As a result, $B$. davidii 'Empire Blue' and $H$. arborescence 'Annabelle' did not need rooting promoter for stem cuttings, and IBA $1,500 \mathrm{mg} \cdot \mathrm{L}^{-1}, \mathrm{IAA} 1,500 \mathrm{mg} \cdot \mathrm{L}^{-1}$ soaking treaments could be used to improve rooting and seedling quality of $H$. paniculata 'Magical Candle' and $S$. incisa semi-hardwood cuttings, respectively.
\end{abstract}

Keywords: butterfly bush, lace shrub, panicle hydrangea, smooth hydrangea

\section{Introduction}

As the culture of gardening has expanded recently, the demand for flowering shrubs for gardens has also continued to increase. Various types of flowering shrubs for gardens are distributed, but most species have been traded on a small scale, except those that have been widely used for landscaping such as Rhododendron spp, Ligustrum obtusifolium, Spireae spp. and Sasa borealis (Park, 2013). This is attributable to the facts that the awareness of plants that can be used for gardening is low, and that technologies to mass-produce and cultivate potential plants for stable production and supply have not been established.

\footnotetext{
This study was supported by the 2017 Post-doctoral Fellowships Program of the National Institute of Horticultural and Herbal Science under the Rural Development Administration (PJ010961022017).

Received: September 8, 2017, Revised: September 25, 2017, Accepted: October 17, 2017

*Comesponding author: baramdosa@korea.kr
} 
Buddleja davidii, commonly called butterfly bush, continues to bloom colorful flowers throughout summer. It can pass the winter well in the central region of Korea because of cold tolerance. It is also resistant to high temperature and dry conditions, and various varieties have been developed. Thanks to its high usability for gardening, it is widely used for potting and cuttings overseas. It is propagated mostly through the tissue culture of leaf explants (Dai and Castillo, 2007) and softwood cutting (Montgomery et al., 1995).

Hydrangea including Hydrangea macrophylla, Hydrangea serrata, H. paniculata and H. arborescence, is widely used for gardening, potting and cutting, and the size of cultivation has continued to increase (RDA, 2003). H. arborescence was first introduced to Korea as an alternative for gardening to Hydrangea macrophylla, a less cold-resistant plant, and it has been also used for cutting. The demand for Hydrangea plants has increased, and various varieties with different colors and shapes have been developed. However, earlier studies on mass-production focused on the softwood cuttings of Hydrangea macrophylla (Ruffoni et al., 2012; Ku and Cho, 2014) and Hydrangea serrata (Lee et al., 2009; Ryu et al., 2010), but only few studies were conducted on $H$. paniculata and $H$. arborescence.

Stephanandra incisa is an indigenous species found in the mountains and fields of Korea. As its small but simple flowers cover trees and have high ornamental values, it is often planted as a boundary tree in landscape projects, and the demand for Stephanandra incisa has increased as well. Those of similar names in Korea such as Physocarpus intermedius and Physocarpus opulifolius have been planted widely in gardens (Kim, 2007). Stephanandra incisa is known to be propagated using softwood cutting or root cutting techniques, but there was no official report on them.

For the propagation of shrubs, cutting techniques are mostly used to maintain the characteristics of shrubs and reduce the time that it takes to start to flower. The rooting and the quality of seedlings when using cutting techniques are affected by various factors such as the timing of cutting (Ko et al., 2007; Lee et al., 2002, 2007), the size and the number of leaves of cuttings (Kil, 2014; Lee et al., 2009), soil for cuttings (Lee et al., 2009), plant growth regulators (Yoo and Kim, 1996; Lee et al., 2007), etc.

Auxin plant growth regulators such as IAA (indole acetic acid), IBA (indole butyric acid) and NAA (naphtalene acetic acid) increase the rooting ratio and the number of roots of plants that cannot be easily propagated by cutting, reduce the time that it takes to start to root, and also improve the quality of seedlings, thus being widely used for commercial plants (Hartmann et al., 2002; Blythe et al., 2007). The effects of rooting promoters differ depending on the type of auxins (Ryu et al., 2010), the concentration level and treatment methods of auxins (Blythe et al., 2007), the type of plants (Chadwick and Kiplinger, 1938), etc. and thus it is necessary to find the right type of auxin and the proper concentration level and treatment method for each plant in order to improve the efficiency of cutting propagation.

In this regard, this study aimed to examine the effects of different auxins and concentration levels on the rooting and the quality of seedlings when propagating those that can be used widely including B. davidii 'Empire Blue,' H. paniculata 'Magical Candle,' H. arborescence 'Annabelle,' and S. incisa using cutting techniques, and to develop fundamental technologies for the stable mass-production of these flowering shrubs.

\section{Methods}

\section{Plant materials and experimental environment}

The following four shrub species that were planted on open grounds in the National Institute of Horticultural and Herbal Science located in Wanju-gun, Jeonbuk, Korea were selected as a plant material in this study: B. davidii 'Empire Blue,' $H$. paniculata 'Magical Candle,' H. arborescence 'Annabelle,' and S. incisa. semi-hardwood branches after growing shoots were collected before 9 a.m. on June 28, 2016, and were dipped in water for an hour. After that, two leaves were attached 
and the length of each plant was prepared as follows: $S$. incisa $(10 \mathrm{~cm}), B$. davidii 'Empire Blue' $(12 \mathrm{~cm}), H$. paniculata 'Magical Candle' $(15 \mathrm{~cm})$, and H. arborescence 'Annabelle' $(15 \mathrm{~cm})$.

To reduce the dryness of leaves caused by transpiration, two thirds of the length of the leaves of $H$. paniculata 'Magical Candle' and H. arborescence 'Annabelle,' and one half of the length of the leaves of B. davidii'Empire Blue' were cut, but the leaves of $S$. incisa were not cut since their length was not long enough.

This study was conducted in a greenhouse in the National Institute of Horticultural and Herbal Science for three months from June 28 to September 28, 2016. To prevent any damage by direct sunlight, the cutting bed in the green house was covered with $70 \%$ black shade net, and the average temperature of the cutting bed was maintained at $25 \pm 2{ }^{\circ} \mathrm{C}$. In addition, the relative humidity of the greenhouse was maintained at over $80 \%$ using an automatic mist sprayer to prevent the dryness of leaves caused by excessive transpiration, and the greenhouse was ventilated two to three times per day to prevent any damage by excessive moisture.

\section{The effects of rooting promoters}

To examine the effects of different auxins, used as a rooting promoter, and their different concentration levels on rooting and seedling quality, Rootone (1-naphthylacetamide 0.4\%, Dongbu Hitek, Korea), IAA (Duchefa, Netherlands), and IBA (Duchefa, Netherlands) were used as a rooting promoter. The bottom of the prepared cuttings for control and Rootone treatment was soaked in water for 30 minutes and their cut section was coated with Rootone. The bottom of the prepared cuttings in the groups treated with IBA and IAA was soaked in $500,1,000$ or $1,500 \mathrm{mg} \cdot \mathrm{L}^{-1} \mathrm{IBA}$ or IAA respectively for 30 minutes, and in $3,000 \mathrm{mg} \cdot \mathrm{L}^{-1}$ for 10 seconds, and the cuttings were planted in a 72-cell tray filled with the soil mixed with vermiculite (Verminuri, GFC Co., Korea) and perlite (Paraso, Samson Co., Korea) at the ratio of 2:1 (v:v). Each treatment (24 units per treatment) was repeated three times. This experiment was conducted using a completely randomized design.

\section{Growth measurement and statistical analysis}

After three months of planting cuttings, the rooting ratio, mat formation, root length, the number of shoots, the number of leaves, shoot length, and the fresh and dry weight of roots and shoots were measured. Mat formation was divided into five stages (1: very poor, 5: very good), and the longest root was measured as root length. The dry weight of roots and shoots was measured after drying them in a dryer $\left(80^{\circ} \mathrm{C}\right)$ for two days.

Data were analyzed using SAS Package (statistical analysis system, ver Enterprise Guide 7.1, SAS Institute Inc.), and significance between the groups was verified using ANOVA (analysis of variance) and Duncan's multiple range test (5\% significance level).

\section{Results and discussion}

The effect of rooting promoters on the rooting ratio of B. davidii 'Empire Blue' was low overall, and the rooting ratio of the group treated with IBA $1,500 \mathrm{mg} \cdot \mathrm{L}^{-1}$ (soaked for 30 minutes) was lower than that of the control group (Table 1). The number of leaves and the length of shoots of the groups treated with Rootone, IBA $1,500 \mathrm{mg} \cdot \mathrm{L}^{-1}$ (soaked for 30 minutes) and 3,000 $\mathrm{mg} \cdot \mathrm{L}^{-1}$ (dipped for 10 seconds) were low, indicating that the growth of shoots was suppressed. The number of shoots and roots differed depending on the type and concentration level of auxins, but the length of shoots, and the fresh and dry weight of shoots were affected only by the concentration level of auxins, not their type. 
Table 1. Effect of auxin treatments on the rooting and shoot growth according to semi-hardwood cuttings in Buddleja davidii“Empire Blue’.

\begin{tabular}{|c|c|c|c|c|c|c|c|c|c|c|c|}
\hline \multirow{2}{*}{\multicolumn{2}{|c|}{$\begin{array}{l}\text { Treatment } \\
\left(\mathrm{mg} \cdot \mathrm{L}^{-1}\right)\end{array}$}} & \multirow{2}{*}{$\begin{array}{c}\text { Rooting } \\
\text { ratio } \\
(\%)\end{array}$} & \multirow{2}{*}{$\begin{array}{c}\text { Mat } \\
\text { formation }^{2}\end{array}$} & \multirow{2}{*}{$\begin{array}{c}\text { Root } \\
\text { length } \\
(\mathrm{cm})\end{array}$} & \multirow{2}{*}{$\begin{array}{c}\text { No. of } \\
\text { shoots } \\
\text { (ea) }\end{array}$} & \multirow{2}{*}{$\begin{array}{c}\text { No. of } \\
\text { leaves. } \\
\text { (ea) }\end{array}$} & \multirow{2}{*}{$\begin{array}{l}\text { Shoot } \\
\text { length } \\
(\mathrm{cm})\end{array}$} & \multicolumn{2}{|c|}{ Root weight } & \multicolumn{2}{|c|}{ Shoot weight } \\
\hline & & & & & & & & F.W. (g) & D.W. (mg) & F.W. (g) & D.W. (mg) \\
\hline Control & & $91.7 \mathrm{a}^{\mathrm{z}}$ & $3.2 \mathrm{c}$ & $7.9 \mathrm{a}-\mathrm{c}$ & $1.8 \mathrm{a}$ & $14.4 \mathrm{ab}$ & $10.8 \mathrm{a}$ & $145.3 \mathrm{~b}$ & $32.3 \mathrm{de}$ & $473.0 \mathrm{ab}$ & $188.8 \mathrm{a}-\mathrm{c}$ \\
\hline Rooton & & $86.7 \mathrm{ab}$ & $3.9 \mathrm{a}-\mathrm{c}$ & $6.7 \mathrm{bc}$ & $1.9 \mathrm{a}$ & $10.5 \mathrm{~cd}$ & $5.3 \mathrm{~cd}$ & $241.0 \mathrm{ab}$ & $38.7 \mathrm{de}$ & $316.7 \mathrm{ab}$ & $111.1 \mathrm{bc}$ \\
\hline \multirow[t]{4}{*}{ IAA } & 500 & $95.0 \mathrm{a}$ & $3.8 \mathrm{a}-\mathrm{c}$ & $8.5 \mathrm{ab}$ & $1.8 \mathrm{a}$ & $17.7 \mathrm{a}$ & $9.0 \mathrm{ab}$ & $140.0 \mathrm{~b}$ & $25.2 \mathrm{e}$ & $383.7 \mathrm{ab}$ & $137.6 \mathrm{a}-\mathrm{c}$ \\
\hline & 1,000 & $88.3 \mathrm{ab}$ & $4.2 \mathrm{ab}$ & $9.2 \mathrm{a}$ & $1.9 \mathrm{a}$ & $17.6 \mathrm{a}$ & $7.7 \mathrm{a}-\mathrm{c}$ & $238.3 \mathrm{ab}$ & $41.2 \mathrm{c}-\mathrm{d}$ & $462.3 \mathrm{ab}$ & $150.6 \mathrm{a}-\mathrm{c}$ \\
\hline & 1,500 & $98.0 \mathrm{a}$ & $4.4 \mathrm{ab}$ & $7.9 \mathrm{a}-\mathrm{c}$ & $1.9 \mathrm{a}$ & $13.7 b c$ & $8.1 \mathrm{a}-\mathrm{c}$ & $313.0 \mathrm{a}$ & $51.0 \mathrm{a}-\mathrm{d}$ & $564.7 \mathrm{a}$ & $170.2 \mathrm{a}-\mathrm{c}$ \\
\hline & 3,000 & $88.3 \mathrm{ab}$ & $4.1 \mathrm{ab}$ & $8.5 \mathrm{ab}$ & $1.9 \mathrm{a}$ & $16.1 \mathrm{ab}$ & $7.7 \mathrm{a}-\mathrm{c}$ & $220.0 \mathrm{ab}$ & $35.5 \mathrm{de}$ & $420.9 \mathrm{ab}$ & $137.7 \mathrm{a}-\mathrm{c}$ \\
\hline \multirow[t]{4}{*}{ IBA } & 500 & $85.0 \mathrm{ab}$ & $4.6 \mathrm{a}$ & $8.5 \mathrm{ab}$ & $1.9 \mathrm{a}$ & $15.1 \mathrm{ab}$ & $9.6 \mathrm{a}$ & $139.0 \mathrm{~b}$ & $70.4 \mathrm{a}$ & $497.7 \mathrm{ab}$ & $207.3 \mathrm{ab}$ \\
\hline & 1,000 & $83.3 \mathrm{ab}$ & $3.6 \mathrm{bc}$ & $8.4 \mathrm{ab}$ & $2.0 \mathrm{a}$ & $14.3 \mathrm{ab}$ & $6.0 \mathrm{~b}-\mathrm{d}$ & $147.3 \mathrm{~b}$ & $45.7 \mathrm{~b}-\mathrm{e}$ & $206.0 \mathrm{~b}$ & $103.2 \mathrm{c}$ \\
\hline & 1,500 & $71.7 \mathrm{~b}$ & $3.8 \mathrm{bc}$ & $6.1 \mathrm{c}$ & $1.6 \mathrm{~b}$ & $8.8 \mathrm{~d}$ & $3.9 \mathrm{~d}$ & $232.7 \mathrm{ab}$ & $62.0 \mathrm{a}-\mathrm{c}$ & $219.3 \mathrm{~b}$ & $107.2 \mathrm{c}$ \\
\hline & 3,000 & $90.0 \mathrm{ab}$ & $3.8 \mathrm{bc}$ & $6.1 \mathrm{c}$ & $1.6 \mathrm{~b}$ & $8.6 \mathrm{~d}$ & $3.8 \mathrm{~d}$ & $303.3 \mathrm{a}$ & $67.7 \mathrm{ab}$ & $555.3 \mathrm{a}$ & $221.9 \mathrm{a}$ \\
\hline \multicolumn{12}{|c|}{ Source of variation ${ }^{\mathrm{x}}$} \\
\hline \multicolumn{2}{|c|}{ Auxin type (A) } & $\mathrm{ns}^{\mathrm{w}}$ & ns & ns & $*$ & ** & ns & ns & ns & ns & * \\
\hline \multicolumn{2}{|c|}{ Concentration (B) } & ns & ns & ns & $* *$ & $* *$ & $* *$ & $*$ & $*$ & $* *$ & $* *$ \\
\hline \multicolumn{2}{|l|}{$A * B$} & ** & $\mathrm{ns}$ & $\mathrm{ns}$ & ns & $\mathrm{ns}$ & ns & ns & ns & * & * \\
\hline
\end{tabular}

${ }^{\mathrm{z}} 1$ (very poor), 2 (poor), 3 (normal), 4 (good), 5 (very good).

${ }^{\mathrm{y}}$ Mean separation within columns by Duncan's multiple range test at $5 \%$ level.

${ }^{\mathrm{x}}$ Analysis of variation was performed only between IBA and IAA treatments.

ws, ${ }^{*}, * *$ non-significant, significant at $P<0.05$ or $p<0.01$ respectively.

The mat formation of cuttings in IAA $1,000,1,500 \mathrm{mg} \cdot \mathrm{L}^{-1}$ (for 30 minutes), and $3,000 \mathrm{mg} \cdot \mathrm{L}^{-1}$ (for 10 seconds) and IBA $500 \mathrm{mg} \cdot \mathrm{L}^{-1}$ (for 30 minutes) was higher than that of the control group. However, since the rooting ratio of the control group was very high (91.7\%), and the growth of the cuttings in Rootone and IBA $1,500 \mathrm{mg} \cdot \mathrm{L}^{-1}$ (for 30 minutes) and 3,000 $\mathrm{mg} \cdot \mathrm{L}^{-1}$ (for 10 seconds) was suppressed, it can be concluded that rooting promoters are not necessary. Still, IAA 1,000, $1,500 \mathrm{mg} \cdot \mathrm{L}^{-1}$ (for 30 minutes) and $3,000 \mathrm{mg} \cdot \mathrm{L}^{-1}$ (for $10 \mathrm{seconds)}$ and IBA $500 \mathrm{mg} \cdot \mathrm{L}^{-1}$ (for 30 minutes) can be also used depending on the mat formation of cuttings in order to improve the quality of seedlings.

Montogomery et al. (1995) reported that the rooting ratio of B. davidii 'Empire Blue' planted using green wood cutting techniques can be improved to $94 \sim 95 \%$ by dipping its cuttings once in a water soluble auxin (K-IBA, 1,500 6,000 $\mathrm{mg} \cdot \mathrm{L}^{-1}$ ), but that the higher the concentration level, the higher the number of roots, and the shorter the length of roots, not affecting the weight of roots. In this study, the length of roots decreased when cuttings were dipped in IBA $1,500 \mathrm{mg} \cdot \mathrm{L}^{-1}$ for 30 minutes and $3,000 \mathrm{mg} \cdot \mathrm{L}^{-1}$ for 10 seconds, showing similar results (Table 1). In terms of the rooting ratio of $B$. davidii, there was no or little significant difference between the control group and the treated groups, The result that the growth of shoots of the groups treated with Rootone (NAA 0.4\%) or high concentration levels of IBA was suppressed more than the groups treated with IAA was not found in the study of Montogomery et al. (1995), but one reason behind it is that the cuttings used in this study were not softwood cuttings but semi-hardwood cuttings.

The rooting ratio of cuttings of $\mathrm{H}$. paniculata 'Magical Candle' dipped in IBA $1,500 \mathrm{mg} \cdot \mathrm{L}^{-1}$ for 30 minutes was $66.7 \%$, up by $40.3 \%$ from that of the control group (26.4\%) (Table 2). It was found that the rooting ratio of cuttings was affected by the type of auxins and its concentration level respectively, and that the rooting ratio of cuttings dipped in IBA was higher than that of cuttings dipped in IAA. It was also found that the higher the concentration level of IBA, the higher the rooting ratio of cuttings, but that the rooting ratio of cuttings dipped in a high concentration (IBA $3,000 \mathrm{mg} \cdot \mathrm{L}^{-1}$, for 10 
Table 2. Effect of auxin treatments on the rooting and shoot growth according to semi-hardwood cuttings in Hydrangea paniculata 'Magical Candle'.

\begin{tabular}{|c|c|c|c|c|c|c|c|c|c|c|c|}
\hline \multirow{2}{*}{\multicolumn{2}{|c|}{$\begin{array}{l}\text { Treatment } \\
\left(\mathrm{mg} \cdot \mathrm{L}^{-1}\right)\end{array}$}} & \multirow{2}{*}{$\begin{array}{l}\text { Rooting } \\
\text { ratio } \\
(\%)\end{array}$} & \multirow{2}{*}{$\begin{array}{c}\text { Mat } \\
\text { formation }^{\mathrm{z}}\end{array}$} & \multirow{2}{*}{$\begin{array}{l}\text { Root } \\
\text { length } \\
(\mathrm{cm})\end{array}$} & \multirow{2}{*}{$\begin{array}{l}\text { No. of } \\
\text { shoots } \\
\text { (ea) }\end{array}$} & \multirow{2}{*}{$\begin{array}{l}\text { No. of } \\
\text { leaves. } \\
\text { (ea) }\end{array}$} & \multirow{2}{*}{$\begin{array}{l}\text { Shoot } \\
\text { length } \\
(\mathrm{cm})\end{array}$} & \multicolumn{2}{|c|}{ Root weight } & \multicolumn{2}{|c|}{ Shoot weight } \\
\hline & & & & & & & & F.W. (g) & D.W. (mg) & F.W. (g) & D.W. (mg) \\
\hline Contro & & $26.4 \mathrm{e}^{\mathrm{y}}$ & $3.9 \mathrm{~b}$ & $6.5 \mathrm{ab}$ & $0.2 \mathrm{~d}$ & $0.9 \mathrm{~d}$ & $1.0 \mathrm{e}$ & $24.6 \mathrm{c}$ & $5.7 \mathrm{a}-\mathrm{c}$ & $17.8 \mathrm{c}$ & $3.0 \mathrm{c}$ \\
\hline Rooton & & $13.9 \mathrm{f}$ & $4.8 \mathrm{a}$ & $4.0 \mathrm{~b}$ & $1.1 \mathrm{~b}-\mathrm{d}$ & $4.0 \mathrm{a}-\mathrm{c}$ & $6.3 \mathrm{~d}$ & $31.7 \mathrm{bc}$ & $3.9 \mathrm{c}$ & $31.4 \mathrm{c}$ & $11.8 \mathrm{bc}$ \\
\hline \multirow[t]{4}{*}{ IAA } & 500 & $19.4 \mathrm{f}$ & $4.1 \mathrm{ab}$ & $7.7 \mathrm{a}$ & $0.9 \mathrm{~cd}$ & $1.9 \mathrm{~cd}$ & $4.4 \mathrm{de}$ & $28.2 \mathrm{bc}$ & $5.6 \mathrm{a}-\mathrm{c}$ & $31.3 \mathrm{c}$ & $8.6 \mathrm{bc}$ \\
\hline & 1,000 & $26.4 \mathrm{e}$ & $4.8 \mathrm{a}$ & $7.9 \mathrm{a}$ & $1.3 \mathrm{a}-\mathrm{c}$ & $3.0 \mathrm{a}-\mathrm{d}$ & $8.8 \mathrm{~b}-\mathrm{d}$ & $43.6 \mathrm{a}-\mathrm{c}$ & $6.7 \mathrm{a}-\mathrm{c}$ & $63.7 \mathrm{bc}$ & $20.1 \mathrm{~b}$ \\
\hline & 1,500 & $44.4 \mathrm{c}$ & $5.0 \mathrm{a}$ & $7.6 \mathrm{a}$ & $2.1 \mathrm{a}$ & $4.2 \mathrm{ab}$ & $11.8 \mathrm{a}-\mathrm{c}$ & $62.6 \mathrm{a}$ & $9.3 \mathrm{a}$ & $63.1 \mathrm{bc}$ & $36.8 \mathrm{a}$ \\
\hline & 3,000 & $26.4 \mathrm{e}$ & $4.8 \mathrm{a}$ & $8.6 \mathrm{a}$ & $1.3 \mathrm{a}-\mathrm{c}$ & $2.2 \mathrm{~b}-\mathrm{d}$ & $8.1 \mathrm{~b}-\mathrm{d}$ & $50.3 \mathrm{a}-\mathrm{c}$ & $8.4 \mathrm{ab}$ & $49.4 \mathrm{bc}$ & $18.9 \mathrm{~b}$ \\
\hline \multirow[t]{4}{*}{ IBA } & 500 & $34.7 \mathrm{~d}$ & $4.8 \mathrm{a}$ & $7.7 \mathrm{a}$ & $1.6 \mathrm{a}-\mathrm{c}$ & $2.2 \mathrm{~b}-\mathrm{d}$ & $8.7 \mathrm{~b}-\mathrm{d}$ & $28.2 \mathrm{bc}$ & $8.9 \mathrm{a}$ & $58.8 \mathrm{bc}$ & $20.9 \mathrm{~b}$ \\
\hline & 1,000 & $52.8 \mathrm{~b}$ & $4.9 \mathrm{a}$ & $6.8 \mathrm{ab}$ & $1.9 \mathrm{ab}$ & $2.4 \mathrm{~b}-\mathrm{d}$ & $12.9 \mathrm{ab}$ & $54.6 \mathrm{ab}$ & $7.6 \mathrm{ab}$ & $100.6 \mathrm{ab}$ & $35.7 \mathrm{a}$ \\
\hline & 1,500 & $66.7 \mathrm{a}$ & $5.0 \mathrm{a}$ & $7.3 \mathrm{a}$ & $2.1 \mathrm{a}$ & $2.8 \mathrm{a}-\mathrm{d}$ & $14.6 \mathrm{a}$ & $47.8 \mathrm{a}-\mathrm{c}$ & $7.3 \mathrm{a}-\mathrm{c}$ & $117.1 \mathrm{a}$ & $43.0 \mathrm{a}$ \\
\hline & 3,000 & $45.8 \mathrm{c}$ & $4.4 \mathrm{ab}$ & $7.8 \mathrm{a}$ & $1.3 \mathrm{~cd}$ & $4.8 \mathrm{a}$ & $7.2 \mathrm{~cd}$ & $33.3 \mathrm{bc}$ & $8.4 \mathrm{a}$ & $60.8 \mathrm{bc}$ & $18.4 \mathrm{~b}$ \\
\hline \multicolumn{12}{|c|}{ Source of variation ${ }^{\mathrm{x}}$} \\
\hline \multicolumn{2}{|c|}{ Auxin type (A) } & $* * \mathrm{w}$ & ns & ns & ns & ns & ns & $\mathrm{ns}$ & $\mathrm{ns}$ & $*$ & $*$ \\
\hline \multicolumn{2}{|c|}{ Concentration (B) } & $* *$ & ns & ns & $*$ & ns & $* *$ & ns & ns & $\mathrm{ns}$ & $* *$ \\
\hline \multicolumn{2}{|c|}{$\mathrm{A} * \mathrm{~B}$} & ns & ns & ns & ns & $*$ & ns & $\mathrm{ns}$ & $* *$ & ns & ns \\
\hline
\end{tabular}

${ }^{\mathrm{z}} 1$ (very poor), 2 (poor), 3 (normal), 4 (good), 5 (very good).

${ }^{\mathrm{y}}$ Mean separation within columns by Duncan's multiple range test at $5 \%$ level.

${ }^{\mathrm{x}}$ Analysis of variation was performed only between IBA and IAA treatments.

ws, ${ }^{*}, *$ non-significant, significant at $P<0.05$ or $p<0.01$ respectively.

seconds) decreased.

The mat formation of the groups treated with Rootone, IAA and IBA was higher than that of the control group. The root length of the groups treated with IAA and IBA, except Rootone, also tended to be longer than the control group, although there was no statistical significance. The number of shoots and leaves and the length of shoots of the groups treated with Rootone, IAA and IBA were higher than the control group. These tended to continue to increase until the concentration level reached $3,000 \mathrm{mg} \cdot \mathrm{L}^{-1}$ (dipped for 10 seconds) since the groups treated with IAA and IBA were affected by their concentration levels. Therefore, it can be concluded that dipping cuttings of $H$. paniculata 'Magical Candle' in IBA 1,500 $\mathrm{mg} \cdot \mathrm{L}^{-1}$ for 30 minutes is effective, but it will be necessary to conduct additional studies in order to increase its rooting ratio.

In the case of H. arborescence 'Annabelle,' the rooting ratio of the groups treated with rooting promoters, except IAA $1,000 \mathrm{mg} \cdot \mathrm{L}^{-1}$ (soaked for 30 minutes), was lower than that of cuttings in the control group (70.8\%), indicating that they suppressed the rooting of cuttings (Table 3). The mat formation of the cuttings of the groups dipped in IBA 1,000 and $1,500 \mathrm{mg} \cdot \mathrm{L}^{-1}$ for 30 minutes was very low, 1.1 and 1.3 respectively, but that of the other treated groups showed similar results to that of the control group. It was found that the number of shoots and leaves, and the length of shoots are affected by the type of auxins, and that they were higher in the groups treated with IAA, regardless of its concentration level, than in the groups treated with IBA. Therefore, it can be concluded that H. arborescence 'Annabelle' shows a relatively high rooting ratio and maintains a high quality of seedlings without rooting promoters. However, since the rooting ratio of the control group was relatively higher than the treated groups, it will be necessary to conduct additional studies on the effects of low concentration levels of auxins below $500 \mathrm{mg} \cdot \mathrm{L}^{-1}$ to improve its rooting ratio.

It was reported that the cuttings of $H$. macrophylla dipped in IBA $500 \sim 1,000 \mathrm{mg} \cdot \mathrm{L}^{-1}$ for 30 minutes (Ku and Cho, 
Table 3. Effect of auxin treatments on the rooting and shoot growth according to semi-hardwood cuttings in Hydrangea arborescens 'Annabelle'.

\begin{tabular}{|c|c|c|c|c|c|c|c|c|c|c|c|}
\hline \multirow{2}{*}{\multicolumn{2}{|c|}{$\begin{array}{l}\text { Treatment } \\
\left(\mathrm{mg} \cdot \mathrm{L}^{-1}\right)\end{array}$}} & \multirow{2}{*}{$\begin{array}{c}\text { Rooting } \\
\text { ratio } \\
(\%)\end{array}$} & \multirow{2}{*}{$\begin{array}{c}\text { Mat } \\
\text { formation }^{\mathrm{z}}\end{array}$} & \multirow{2}{*}{$\begin{array}{l}\text { Root } \\
\text { length } \\
(\mathrm{cm})\end{array}$} & \multirow{2}{*}{$\begin{array}{c}\text { No. of } \\
\text { shoots } \\
\text { (ea) }\end{array}$} & \multirow{2}{*}{$\begin{array}{l}\text { No. of } \\
\text { leaves. } \\
\text { (ea) }\end{array}$} & \multirow{2}{*}{$\begin{array}{l}\text { Shoot } \\
\text { length } \\
(\mathrm{cm})\end{array}$} & \multicolumn{2}{|c|}{ Root weight } & \multicolumn{2}{|c|}{ Shoot weight } \\
\hline & & & & & & & & F.W. (g) & D.W. (mg) & F.W. (g) & D.W. (mg) \\
\hline Contr & & $70.8 \mathrm{a}^{\mathrm{y}}$ & $3.3 \mathrm{a}$ & $8.1 \mathrm{ab}$ & $0.9 \mathrm{a}-\mathrm{c}$ & $3.3 \mathrm{a}-\mathrm{c}$ & $1.2 \mathrm{a}$ & $7.8 \mathrm{bc}$ & $4.5 \mathrm{a}$ & $11.1 \mathrm{bc}$ & $4.9 \mathrm{bc}$ \\
\hline Rooto & & $37.5 \mathrm{c}$ & $3.4 \mathrm{a}$ & $8.5 \mathrm{ab}$ & $0.0 \mathrm{~d}$ & $0.0 \mathrm{c}$ & $0.0 \mathrm{c}$ & $5.9 \mathrm{bc}$ & $4.6 \mathrm{a}$ & $0.0 \mathrm{c}$ & $0.0 \mathrm{c}$ \\
\hline \multirow[t]{4}{*}{ IAA } & 500 & $54.2 \mathrm{~b}$ & $2.9 \mathrm{a}$ & $6.5 \mathrm{bc}$ & $1.1 \mathrm{a}-\mathrm{c}$ & $5.1 \mathrm{ab}$ & $1.4 \mathrm{ab}$ & $5.4 \mathrm{bc}$ & $3.1 \mathrm{a}-\mathrm{c}$ & $10.2 \mathrm{bc}$ & $5.4 \mathrm{bc}$ \\
\hline & 1,000 & $66.7 \mathrm{a}$ & $3.3 \mathrm{a}$ & $7.7 \mathrm{ab}$ & $1.3 \mathrm{ab}$ & $6.7 \mathrm{a}$ & $2.2 \mathrm{a}$ & $13.8 \mathrm{a}-\mathrm{c}$ & $4.6 \mathrm{a}$ & $45.2 \mathrm{a}$ & $18.0 \mathrm{a}$ \\
\hline & 1,500 & $20.3 \mathrm{~d}$ & $3.1 \mathrm{a}$ & $7.9 a b$ & $1.1 \mathrm{a}-\mathrm{c}$ & $6.7 \mathrm{a}$ & $1.9 \mathrm{a}$ & $17.3 \mathrm{a}-\mathrm{c}$ & $4.6 \mathrm{a}$ & $19.3 \mathrm{bc}$ & $8.0 \mathrm{bc}$ \\
\hline & 3,000 & $21.7 \mathrm{~d}$ & $3.4 \mathrm{a}$ & $9.5 \mathrm{a}$ & $1.4 \mathrm{a}$ & $7.2 \mathrm{a}$ & $2.1 \mathrm{a}$ & $26.6 \mathrm{a}$ & $5.7 \mathrm{a}$ & $33.3 \mathrm{ab}$ & $12.5 \mathrm{ab}$ \\
\hline \multirow[t]{4}{*}{ IBA } & 500 & $19.2 \mathrm{~d}$ & $3.2 \mathrm{a}$ & $9.1 \mathrm{ab}$ & $0.6 \mathrm{~b}-\mathrm{d}$ & $3.1 \mathrm{a}-\mathrm{c}$ & $0.8 \mathrm{bc}$ & $20.6 \mathrm{ab}$ & $3.8 \mathrm{ab}$ & $17.2 \mathrm{bc}$ & $5.4 \mathrm{bc}$ \\
\hline & 1,000 & $7.3 \mathrm{e}$ & $1.1 \mathrm{~b}$ & $4.4 \mathrm{~cd}$ & $0.0 \mathrm{~d}$ & $0.0 \mathrm{c}$ & $0.0 \mathrm{c}$ & $3.6 \mathrm{c}$ & $0.9 \mathrm{c}$ & $0.0 \mathrm{c}$ & $0.0 \mathrm{c}$ \\
\hline & 1,500 & $3.3 \mathrm{e}$ & $1.3 \mathrm{~b}$ & $2.3 \mathrm{~d}$ & $0.3 \mathrm{~cd}$ & $2.0 \mathrm{bc}$ & $0.7 \mathrm{bc}$ & $7.3 \mathrm{bc}$ & $1.2 \mathrm{c}$ & $3.3 \mathrm{c}$ & $1.6 \mathrm{c}$ \\
\hline & 3,000 & $50.0 \mathrm{~b}$ & $3.7 \mathrm{a}$ & $9.0 \mathrm{ab}$ & $1.1 \mathrm{a}-\mathrm{c}$ & $4.9 \mathrm{ab}$ & $2.1 \mathrm{a}$ & $25.8 \mathrm{a}$ & $5.0 \mathrm{a}$ & $33.3 \mathrm{ab}$ & $12.5 \mathrm{ab}$ \\
\hline \multicolumn{12}{|c|}{ Source of variation ${ }^{\mathrm{x}}$} \\
\hline \multicolumn{2}{|c|}{ Auxin type (A) } & $* *^{\mathrm{w}}$ & ns & ns & $* *$ & $* *$ & $* *$ & ns & $*$ & $* *$ & $* *$ \\
\hline \multicolumn{2}{|c|}{ Concentration (B) } & $* *$ & $*$ & $*$ & $*$ & ns & ns & $*$ & $*$ & ns & ns \\
\hline \multicolumn{2}{|c|}{$\mathrm{A} * \mathrm{~B}$} & $* *$ & * & * & ns & ns & $*$ & ns & $*$ & $*$ & $*$ \\
\hline
\end{tabular}

${ }^{\mathrm{z}} 1$ (very poor), 2 (poor), 3 (normal), 4 (good), 5 (very good).

${ }^{\mathrm{y}}$ Mean separation within columns by Duncan's multiple range test at $5 \%$ level.

${ }^{\mathrm{x}}$ Analysis of variation was performed only between IBA and IAA treatments.

ws, ${ }^{*}, *$ non-significant, significant at $P<0.05$ or $p<0.01$ respectively.

2014), and that the green wood cuttings of $H$. macrophylla for. acuminata dipped once in IBA $500 \mathrm{mg} \cdot \mathrm{L}^{-1}$ (Lee et al., 2007) or dipped in IBA $50 \mathrm{mg} \cdot \mathrm{L}^{-1}$ for 3 hours (Park and Kim, 1993); and the cuttings of $H$. paniculata dipped in IBA $1,000 \mathrm{mg} \cdot \mathrm{L}^{-1}+\mathrm{NAA} 500 \mathrm{mg} \cdot \mathrm{L}^{-1}$ for 1 second (Blythe et al., 2003) showed better rooting showed improved rooting ratios. The semi-hardwood cuttings of $H$. paniculata 'Magical Candle' dipped in IBA showed similar rooting ratios to the results of the studies above, but the rooting ratio was relatively low (66.7\%). This can be attributable to various factors, including the characteristics of the 'Magical Candle' variety, and using semi-hardwood cuttings.

The rooting ratio of the cuttings of $S$. incisa dipped in Rootone and IAA $1,500 \mathrm{mg} \cdot \mathrm{L}^{-1}$ for 30 minutes was higher $(80 \%)$ than that of the control group (51.7\%) (Table 4). The maximum length and the dry weight of roots of cuttings dipped in IAA $1,500 \mathrm{mg} \cdot \mathrm{L}^{-1}$ for 30 minutes were high $(8.1 \mathrm{~cm}$ and $25.7 \mathrm{mg}$ respectively), and the number, length and dry weight of shoots were also high. The mat formation of cuttings dipped in $3,000 \mathrm{mg} \cdot \mathrm{L}^{-1}$ for 10 seconds showed a normal level (3.4), and that of cuttings in the other treated groups was very low (all below 2.3). The number of shoots and leaves, and the dry weight of shoots were affected by the type and concentration level of auxins respectively, but the length of shoots, the fresh and dry weight of roots, and the fresh weight of shoots were affected only by the concentration level of auxins regardless of the type of auxins. Therefore, it seems to be more effective to soak $S$. incisa in IAA $1,500 \mathrm{mg} \cdot \mathrm{L}^{-1}$ for 30 minutes in order to improve its rooting ratio and seedling quality, but it will be still necessary to conduct additional studies to improve its mat formation.

These results indicated that IBA was effective for H. paniculata 'Magical Candle' (Table 2), while IAA was more effective for the cuttings of $H$. arborescence 'Annabelle' and $S$. incisa (Table 3, 4). The reason behind it seems to be that different types of auxins are suitable for different types of plants. It was reported that IBA is more effective in general for the rooting and growth of shoots than NAA or IAA (Dirr, 1992; Lee et al., 2007; Ryu et al., 2010), and that IBA is more 
Table 4. Effect of auxin treatments on the rooting and shoot growth according to semi-hardwood cuttings in Stephandra incisa.

\begin{tabular}{|c|c|c|c|c|c|c|c|c|c|c|c|}
\hline \multirow{2}{*}{\multicolumn{2}{|c|}{$\begin{array}{l}\text { Treatment } \\
\left(\mathrm{mg} \cdot \mathrm{L}^{-1}\right)\end{array}$}} & \multirow{2}{*}{$\begin{array}{c}\text { Rooting } \\
\text { ratio } \\
(\%)\end{array}$} & \multirow{2}{*}{$\begin{array}{c}\text { Mat } \\
\text { formation }^{\mathrm{z}}\end{array}$} & \multirow{2}{*}{$\begin{array}{l}\text { Root } \\
\text { length } \\
(\mathrm{cm})\end{array}$} & \multirow{2}{*}{$\begin{array}{c}\text { No. of } \\
\text { shoots } \\
\text { (ea) }\end{array}$} & \multirow{2}{*}{$\begin{array}{c}\text { No. of } \\
\text { leaves. } \\
\text { (ea) }\end{array}$} & \multirow{2}{*}{$\begin{array}{c}\text { Shoot } \\
\text { length } \\
(\mathrm{cm})\end{array}$} & \multicolumn{2}{|c|}{ Root weight } & \multicolumn{2}{|c|}{ Shoot weight } \\
\hline & & & & & & & & F.W. (g) & D.W. (mg) & F.W. (g) & D.W. (mg) \\
\hline Contr & & $51.7 \mathrm{bc}^{\mathrm{y}}$ & $1.8 \mathrm{ab}$ & $6.5 \mathrm{ab}$ & $1.0 \mathrm{a}$ & $4.5 \mathrm{a}$ & $2.1 \mathrm{ab}$ & $16.0 \mathrm{c}$ & $14.7 \mathrm{bc}$ & $55.0 \mathrm{bc}$ & $32.3 \mathrm{bc}$ \\
\hline Rooto & & $80.0 \mathrm{a}$ & $2.3 \mathrm{ab}$ & $6.1 \mathrm{ab}$ & $0.9 \mathrm{ab}$ & $3.0 \mathrm{~b}-\mathrm{d}$ & $1.6 \mathrm{a}-\mathrm{c}$ & $68.7 \mathrm{ab}$ & $20.3 \mathrm{ab}$ & $89.0 \mathrm{ab}$ & $39.3 \mathrm{ab}$ \\
\hline \multirow[t]{4}{*}{ IAA } & 500 & $55.0 \mathrm{bc}$ & $1.7 \mathrm{ab}$ & $7.4 \mathrm{a}$ & $1.0 \mathrm{a}$ & $4.1 \mathrm{a}-\mathrm{c}$ & $1.5 \mathrm{a}-\mathrm{c}$ & $40.3 \mathrm{a}-\mathrm{c}$ & $17.3 \mathrm{a}-\mathrm{c}$ & $64.0 \mathrm{bc}$ & $28.6 \mathrm{~b}-\mathrm{d}$ \\
\hline & 1,000 & $50.0 \mathrm{bc}$ & $1.0 \mathrm{~b}$ & $6.6 \mathrm{ab}$ & $0.7 \mathrm{bc}$ & $2.3 \mathrm{de}$ & $1.0 \mathrm{~cd}$ & $12.0 \mathrm{c}$ & $8.5 \mathrm{c}$ & $19.3 \mathrm{c}$ & $9.2 \mathrm{e}$ \\
\hline & 1,500 & $80.0 \mathrm{a}$ & $2.3 \mathrm{ab}$ & $8.1 \mathrm{a}$ & $1.0 \mathrm{a}$ & $4.3 \mathrm{ab}$ & $2.2 \mathrm{a}$ & $76.3 \mathrm{a}$ & $25.7 \mathrm{a}$ & $125.0 \mathrm{a}$ & $51.1 \mathrm{a}$ \\
\hline & 3,000 & $60.0 \mathrm{a}-\mathrm{c}$ & $2.3 \mathrm{ab}$ & $6.6 \mathrm{ab}$ & $1.0 \mathrm{a}$ & $4.3 \mathrm{ab}$ & $1.9 \mathrm{a}-\mathrm{c}$ & $40.3 \mathrm{a}-\mathrm{c}$ & $18.4 \mathrm{a}-\mathrm{c}$ & $88.0 \mathrm{ab}$ & $35.7 \mathrm{a}-\mathrm{c}$ \\
\hline \multirow[t]{4}{*}{ IBA } & 500 & $50.0 \mathrm{bc}$ & $2.0 \mathrm{ab}$ & $6.4 \mathrm{ab}$ & $0.9 \mathrm{ab}$ & $2.6 \mathrm{de}$ & $1.3 \mathrm{~b}-\mathrm{d}$ & $56.3 \mathrm{a}-\mathrm{c}$ & $17.4 \mathrm{a}-\mathrm{c}$ & $50.0 \mathrm{bc}$ & $21.2 \mathrm{~b}-\mathrm{e}$ \\
\hline & 1,000 & $66.7 \mathrm{ab}$ & $1.9 \mathrm{ab}$ & $5.1 \mathrm{~b}$ & $0.6 \mathrm{c}$ & $1.4 \mathrm{e}$ & $0.5 \mathrm{~d}$ & $25.7 \mathrm{bc}$ & $11.4 \mathrm{bc}$ & $34.6 \mathrm{c}$ & $12.4 \mathrm{de}$ \\
\hline & 1,500 & $36.7 \mathrm{c}$ & $1.4 \mathrm{ab}$ & $6.6 \mathrm{ab}$ & $0.7 \mathrm{bc}$ & $2.8 \mathrm{~cd}$ & $1.9 \mathrm{ab}$ & $47.3 \mathrm{a}-\mathrm{c}$ & $13.4 \mathrm{bc}$ & $49.0 \mathrm{bc}$ & $17.8 \mathrm{c}-\mathrm{e}$ \\
\hline & 3,000 & 71. ab & $3.4 \mathrm{a}$ & $6.7 \mathrm{ab}$ & $0.9 \mathrm{a}$ & $3.3 \mathrm{a}-\mathrm{d}$ & $1.9 \mathrm{ab}$ & $52.3 \mathrm{a}-\mathrm{c}$ & $19.6 \mathrm{ab}$ & $87.3 \mathrm{ab}$ & $32.8 \mathrm{bc}$ \\
\hline \multicolumn{12}{|c|}{ Source of variation ${ }^{\mathrm{x}}$} \\
\hline \multicolumn{2}{|c|}{ Auxin type (A) } & $\mathrm{ns}^{\mathrm{w}}$ & ns & ns & $*$ & $* *$ & ns & ns & ns & ns & $*$ \\
\hline \multicolumn{2}{|c|}{ Concentration (B) } & ns & ns & ns & $* *$ & $* *$ & $* *$ & $*$ & $*$ & $* *$ & $* *$ \\
\hline \multicolumn{2}{|l|}{$A^{*} \mathrm{~B}$} & $* *$ & ns & ns & ns & ns & ns & ns & ns & $*$ & $*$ \\
\hline
\end{tabular}

${ }^{\mathrm{z}} 1$ (very poor), 2 (poor), 3 (normal), 4 (good), 5 (very good).

${ }^{\mathrm{y}}$ Mean separation within columns by Duncan's multiple range test at $5 \%$ level.

${ }^{\mathrm{x}}$ Analysis of variation was performed only between IBA and IAA treatments.

ws, ${ }^{*}, *$ non-significant, significant at $P<0.05$ or $p<0.01$ respectively.

effective in a low concentration level than IAA (Ludwig-Müller et al., 1993). However, it was also reported that IAA is more effective for green wood cuttings of Abeliophyllum distichum (Yoo and Kim, 1996), Juniperus chinensis var. sargentii, (Song et al., 2010), and Rosa davurica (Lee te al., 2000), IAA was more effective, and that NAA is more effective for Rhododendron brachycarpum (Hwang et al., 2015) and Rosa davurica (Lee et al., 2000) than IBA. Considering these results, it can be concluded that the type and concentration level of auxins suitable for cuttings differ depending on the species or variety of plants.

\section{Conclusions}

The results above indicated that rooting promoters are not needed for the mass-production of B. davidii 'Empire Blue' and $H$. arborescence 'Annabelle'using cutting techniques. It was found that $S$. incisa and $H$. paniculata 'Magical Candle'need to be soaked in IAA $1,500 \mathrm{mg} \cdot \mathrm{L}^{-1}$ and IBA $1,500 \mathrm{mg} \cdot \mathrm{L}^{-1}$ for 30 minutes respectively in order to improve their rooting ratio and seedling quality. It will be necessary to conduct additional studies on methods to increase the mat formation of H. arborescence 'Annabelle' and S. incisa.

\section{References}

Blythe, E.K., J.L. Sibley, K.M. Tilt, and J.M. Ruter. 2003. Foliar application of auxin for rooting stem cuttings of selected ornamental plants. J. Environ. Hortic. 21(3):131-136.

Blythe, E.K., J.L. Sibley, K.M. Tilt, and J.M. Ruter. 2007. Methods of auxin application in cutting propagation: A review of 
70 years of scientific discovery and commercial practice. J. Environ. Hortic. 25(3):166-185.

Chadwick, L.C. and D.C. Kiplinger. 1938. The effect of synthetic growth substances on the rooting and subsequent growth of ornamental plants. Proc. Am. Soc. Hort. Sci. 36:809-816.

Dai, W. and C. Castillo. 2007. Factors affecting plant regeneration from leaf tissues of Buddleja species. HortScience 42(7):1670-1673.

Dirr, M.A. 1992. Update on root-promoting chemicals and formulations. Comb. Proc. Intl. Plant Prop. Soc. 42:361-365.

Hartmann, H.T., D.E. Kester, F.T. Davies, Jr., and R.L. Geneve. 2002. Plant propagation: Principles and Practices. $7^{\text {th }}$ ed. New Jersey, USA: Prentice Hall.

Hwang, Y., C.Y. Song, J.Y. Moon, J.H. Lee, and Y.Y. Kim. 2015. Effect of cutting time, rooting promoter and light shade on rooting of Rhododendron brachycarpum native to Korea. Flower Res. J. 23(1):37-42. DOI: 10.11623/frj.2015.23.9

Kil, M.J., B.S. Yoo, J.A. Jung, and Y.S. Kwon. 2014. Effects of cutting node, rooting promoter, and media on adventitious rooting of stem cutting in Clematis. J. Kor. Soc. People Plants Environ. 17(6):477-482. DOI: 10.11628/ksppe.2014.17.6.477

Kim, S.S. 2007. An illustrated encyclopedia of woody landscape plants in Korea. Seoul, Korea: Kimoondang.

Ko, J.Y., H.J. Kwon, and M.H. An. 2007. Effects of cutting time and plant growth regulators on rooting of Potentilla fruticosa L. Korean J. Hortic. Sci. Technol. 25(4):463-467.

Ku, B.S. and M.S. Cho. 2014. Effects of IBA and rooting media on rooting of cut Hydrangea macrophylla. Flower Res. J. 22(2):60-67. DOI: 10.11623/frj.2014.22.2.4

Lee, H.D., S.D. Kim, H.H. Kim, J.W. Lee, J.H. Kim, T. Tae, H.C. Lee, and H.C. Lee. 2002. Effect of cutting time, cultivation media and growth regulators on rooting of Weigela subsessilis L. H. Bailey cuttings. Korean J. Plant Resour. 15(3):269-278.

Lee, H.Y., J.D. Lim, I.S. Kim, I.M. Chung, and C.Y. Yu. 2000. Effect of cutting type, growth regulators and propagation media on rooting and root growth of on Rosa davurica Pall. Korean J. Plant Resour. 13(2):140-146.

Lee, J.S., S.W. Han, H.J. Kim, and N.Y. Lee. 2007. Effect of cutting period and IBA, NAA, rootone on the rooting of Hydrangea serrata. J. Korean Soc. Plant People Environ. 10(3):131-134.

Lee, S.Y., N.H. Yoon, J.H. Gu, S.J. Jeong, K.J. Kim, J.C. Rhee, T.J. Lee, and J.S. Lee. 2009. Effect of leaf number and rooting media on adventitious rooting of softwood cuttings in native Hydrangea serrata for. acuminata. Korean J. Hortic. Sci. Technol. 27(2):199-204.

Ludwig-Müller, J., S. Sass, E.G. Sutter, M. Wodner, and E. Epstein. 1993. Indole-3-butyric acid in Arabidopsis thaliana I. Identification and quantification. Plant Growth Regul. 13(2):179-187.

Montgomery, C.C., B.K. Behe, D.J. Eakes, T.S. Kreantz, and V.V. Allen. 1995. Cultivar and IBA concentration influence rooting of Buddleja. HortScience 30(3):426.

Park, W.K. 2013. An analysis of the price fluctation of landscaping plants. J. Korea Soc. Environ. Restor. Technol. 16(6):63-75. DOI : 10.13087/kosert.2013.16.6.063

Park, Y.J. and H.K. Kim. 1993. Studies on factors influencing the rooting of Hydrangea serrata Seringe var. oamacha Honda cutting. J. East Coast. Res. 4(1):61-69.

Ruffoni, B., E. Sacco, and M. Savona. 2012. In Vitro Propagation of Hydrangea spp. Protocols for Micropropagation of Selected Economically-Important Horticultural Plants, 231-244.

RDA (Rural Development Administration). 2003. Cultivation of ornamental flowering shrubs. Suwon, Korea: RDA.

Ryu, M.J., B.M. Park, and J.H. Bae. 2010. Effect of IBA, and NAA on the rooting of wild Hydrangea serrata for. acuminata. Prot. Hortic. Plant Fact. 19(4):397-402.

Song, J.H., K.H. Jang, and S.D. Hur. 2010. Propagation of cutting method of a rare endemic Juniperus chinensis var. sargentii Henry in Korea. Korean J. Plant Resour. 23(4):368-373.

Yoo, Y.K. and K.S. Kim. 1996. Seasonal variation in rooting ability, plant hormones, carbohydrate, nitrogen, starch, and soluble sugar contents in cuttings of white forsythia. J. Korean Soc. Hortic. Sci. 37(4):554-560. 